Krzysztof Świtała*

\title{
KONCEPCJA SYSTEMU INFORMACJI W OCHRONIE ZDROWIA - DECENTRALIZACJA CZY CENTRALIZACJA PROCESÓW PRZETWARZANIA DANYCH DOTYCZACYCH ZDROWIA? ${ }^{1}$
}

Informacja - rozumiana jako przenaszalne, niematerialne dobro zmniejszające niepewność - staje się istotnym czynnikiem rozwoju nowoczesnych społeczeństw postindustrialnych i gospodarek opartych na wiedzy ${ }^{2}$. Trendy te widoczne są także w sektorze ochrony zdrowia, gdzie coraz większe znaczenie zyskuje koncepcja medycyny opartej na faktach (ang. evidence-based medicine), której skuteczna realizacja wymaga zastosowania efektywnych, częściowo zautomatyzowanych procesów analizy dużych zbiorów danych dotyczących procesów leczenia poszczególnych grup pacjentów. Jak podkreśla E. Schmidt-Assmann, w praktyce administracyjnej uwzględniać należy „pozytywne wartości nowych technik informacyjnych i otwierane dzięki nim możliwości bardziej bezpośredniego, szybszego i wyczerpującego uzyskanie informacji w sprawie zjawisk i warunków”3.

* Krzysztof Świtała - Wydział Prawa i Administracji Uniwersytetu Kardynała Stefana Wyszyńskiego.

1 Opracowanie to powstało w ramach projektu badawczego Preludium finansowanego przez Narodowe Centrum Nauki (2014/13/N/HS5/03523).

2 G. Szpor, Informacja w zagospodarowaniu przestrzennym, Katowice 1998, s. 13.

${ }^{3}$ E. Schmidt-Assmann, Ogólne prawo administracyjne jako idea porządku. Założenia i zadania tworzenia systemu prawnoadministracyjnego, Warszawa 2011, s. 353. 
Doświadczenia takich krajów jak Australia, Wielka Brytania czy Kanada wskazują, że zbiory danych gromadzonych w ochronie zdrowia stanowią użyteczny instrument wspomagający kształtowanie polityk publicznych ${ }^{4}$. W tym kontekście należy zwrócić uwagę, że jednym z obszarów działań w ramach Europejskiej Agendy Cyfrowej, będącej jednym z siedmiu projektów przewodnich strategii Europa 2020, jest zapewnianie mieszkańcom Unii Europejskiej stabilnej opieki zdrowotnej i wsparcia dla godnego i niezależnego życia, przy wykorzystaniu możliwości technologii informacyjno-komunikacyjnych ${ }^{5}$.

Podstawy prawne funkcjonowania systemu informacji w ochronie zdrowia wynikają z ustawy z 28.10.2011 r. o systemie informacji w ochronie zdrowia ${ }^{6}$. Stanowi on istotny element infrastruktury informacyjnej państwa, będącej kompleksem instytucji, jednostek organizacyjnych, zasobów i systemów informacyjnych, a także technologii informacyjno-komunikacyjnych, których odpowiednie wykorzystywanie warunkuje optymalne funkcjonowanie określonych systemów społecznych, ekonomicznych i politycznych ${ }^{7}$. Zgodnie z art. 1 ust. 1 u.s.i.o.z. w omawianym systemie informacji przetwarza się dane niezbędne do prowadzenia polityki zdrowotnej państwa, podnoszenia jakości i dostępności świadczeń opieki zdrowotnej oraz finansowania zadań z zakresu ochrony zdrowia.

W piśmiennictwie z zakresu nauk o zarządzaniu system informacyjny rozpatruje się jako „wielopoziomową strukturę, która pozwala użytkownikowi tego systemu na transformowanie określonych informacji wejścia na pożądane informacje wyjścia za pomocą odpowiednich procedur i modeli" ${ }^{\text {. }}$. W przepisach polskiego prawa w art. 2 pkt 13

${ }^{4}$ L. Roos, V. Menec, R. Currie, Policy analysis in an information-rich environment, „Social Science \& Medicine” 2004/58, s. 2238-2239.

${ }^{5}$ Komunikat Komisji do Parlamentu Europejskiego, Rady, Europejskiego Komitetu Ekonomiczno-Społecznego i Komitetu Regionów „Europejska agenda cyfrowa” (COM/2010/0245), s. 33-35.

${ }^{6}$ Dz.U. z 2017 r. poz. 1845 ze zm. - dalej jako: u.s.i.o.z.

7 J. Oleński, Infrastruktura informacyjna państwa $w$ globalnej gospodarce, Warszawa 2006, s. 270-271.

${ }^{8} \mathrm{~J}$. Kisielnicki, H. Sroka, Systemy informacyjne biznesu. Informatyka dla zarzadzania, Warszawa 2005, s. 18. 
ustawy z 29.06.1995 r. o statystyce publicznej ${ }^{9}$ odnajdziemy także definicję pokrewnego pojęcia prawnego systemów informacyjnych administracji publicznej obejmujących systemy zbierania, gromadzenia i przetwarzania informacji przez organy administracji publicznej, Zakład Ubezpieczeń Społecznych, Narodowy Fundusz Zdrowia, Komisję Nadzoru Finansowego, organy rejestrowe, inne państwowe lub samorządowe osoby prawne oraz inne podmioty prowadzące rejestry urzędowe.

Jak wskazuje treść art. 4 ust. 3 u.s.i.o.z. zasoby systemu informacji w ochronie zdrowia obejmują dane osobowe pacjentów (takie jak imię i nazwisko, płeć, obywatelstwo, wykształcenie, numer PESEL, datę urodzenia czy informację o prawie do świadczeń opieki zdrowotnej finansowanych ze środków publicznych), jednostkowe dane medyczne ${ }^{10}$ i daty dokonywania wpisów. Na podstawie art. 5 ust. 1 u.s.i.o.z. przetwarzane są one w ramach:

1) Systemu Informacji Medycznej (SIM) - jest to system teleinformatyczny służący przetwarzaniu danych dotyczących udzielonych, udzielanych i planowanych świadczeń opieki zdrowotnej udostępnianych przez systemy teleinformatyczne usługodawców (art. 10 ust. 1 u.s.i.o.z.);

2) dziedzinowych systemów informatycznych - systemów teleinformatycznych wspomagających określony obszar funkcjonowania systemu ochrony zdrowia (art. 2 pkt 5 u.s.i.o.z.). Ich integracja z systemem informacji w ochronie zdrowia ma umożliwiać skuteczną wymianę danych medycznych w istotnych z punktu widzenia zdrowia publicznego obszarach, a także zapewniać zgodność takich procesów z powszechnie przyjętymi i wspólnymi dla wszystkich elementów tego środowiska standardami semantycznymi i technicznymi ${ }^{11}$. Do tej grupy systemów należą:

${ }^{9}$ Dz.U. z 2018 r. poz. 997 ze zm.

${ }_{10}$ Zgodnie $\mathrm{z}$ definicją zawartą $\mathrm{w}$ art. 2 pkt 7 u.s.i.o.z. są to dane osobowe oraz inne dane osób fizycznych dotyczące uprawnień do udzielonych, udzielanych i planowanych świadczeń opieki zdrowotnej, stanu zdrowia, a także inne dane przetwarzane w związku z planowanymi, udzielanymi i udzielonymi świadczeniami opieki zdrowotnej oraz profilaktyką zdrowotną i realizacją programów zdrowotnych.

11 D. Wąsik, Ustawa o systemie informacji w ochronie zdrowia. Komentarz, Warszawa 2015 , s. 32-33. 

a) System RUM - NFZ - Rejestr Usług Medycznych Narodo- wego Funduszu Zdrowia,
b) System Statystyki w Ochronie Zdrowia,
c) System Ewidencji Zasobów Ochrony Zdrowia,
d) System Monitorowania Zagrożeń,
e) System Monitorowania Dostępności do Świadczeń Opieki Zdrowotnej,
f) System Monitorowania Kosztów Leczenia,
g) Zintegrowany System Monitorowania Obrotu Produktami Leczniczymi,
h) System Monitorowania Kształcenia Pracowników Medycz- nych,
i) System Obsługi List Refundacyjnych,
j) Instrument Oceny Wniosków Inwestycyjnych w Sektorze Zdrowia;

3) rejestrów medycznych - tworzonych zgodnie z prawem rejestrów, ewidencji, list, spisów albo innych uporządkowanych zbiorów danych osobowych, jednostkowych danych medycznych lub danych niebędących danymi osobowymi, służących do realizacji zadań publicznych, prowadzonych przez podmiot funkcjonujący w systemie ochrony zdrowia (art. 2 pkt 12 u.s.i.o.z.).

Koncepcja systemu informacji w ochronie zdrowia zakłada także istnienie warstwy integracyjnej realizującej procesy wymiany danych pomiędzy poszczególnymi jego elementami. Ten fragment infrastruktury informacyjnej państwa obsługiwany będzie przez dwa wyspecjalizowane systemy teleinformatyczne:

1) Platformę Udostępniania On-Line Usług i Zasobów Cyfrowych Rejestrów Medycznych (P2) - rozwiązanie to umożliwia współpracę Systemu Informacji Medycznej z rejestrami medycznymi w celu pozyskiwania danych w nich przetwarzanych, ich integracji, aktualizacji i udostępniania zasobów informacyjnych usługodawcom i płatnikom, w zakresie posiadanych przez te podmioty uprawnień (art. 6 ust. 1 u.s.i.o.z.);

2) Elektroniczną Platformę Gromadzenia, Analizy i Udostępnienia Zasobów Cyfrowych o Zdarzeniach Medycznych (P1) - narzędzie to umożliwi dostęp usługobiorców i innych uprawnionych 
podmiotów do przekazywanych przez usługodawców do SIM informacji i raportów o już udzielonych i zaplanowanych świadczeniach zdrowotnych. Będąca częścią tego rozwiązania uniwersalna szyna usług (ang. Enterprise Service Bus) zapewni wymianę danych zawartych w elektronicznej dokumentacji medycznej pomiędzy uprawnionymi podmiotami, jeżeli będzie to niezbędne do zapewnienia ciągłości leczenia. Dodatkowo omawiany system pozwoli na dostęp podmiotów prowadzących rejestry medyczne, w zakresie realizowanych zadań i posiadanych uprawnień, do danych przetwarzanych w SIM (art. 7 ust. 1 u.s.i.o.z.).

Do października 2017 r. udało się zbudować jedynie część dziedzinowych systemów teleinformatycznych przewidzianych w pierwotnej koncepcji struktury systemu informacji w ochronie zdrowia i powiązać z nowymi rozwiązaniami tylko niektóre rejestry medyczne ${ }^{12}$. W 2013 r. wdrożono system P2, zaś nad kluczową dla pełnej integracji poszczególnych elementów systemu informacji ochrony zdrowia platformą P1 prace nadal trwają ${ }^{13}$.

${ }^{12}$ Do 12.10 .2018 r. z będącą elementem systemu informacji w ochronie zdrowia platformą P2 zintegrowano następujące rejestry: rejestr podmiotów wykonujących działalność leczniczą; rejestr zezwoleń na prowadzenie aptek ogólnodostępnych, punktów aptecznych oraz rejestr udzielonych zgód na prowadzenie aptek szpitalnych, zakładowych i działów farmacji szpitalnej, rejestr zezwoleń na prowadzenie hurtowni farmaceutycznej; rejestr produktów leczniczych - obejmujący rejestr produktów leczniczych dopuszczonych do obrotu na terytorium Rzeczypospolitej Polskiej oraz wspólnotowy rejestr produktów leczniczych; lista diagnostów laboratoryjnych; rejestr systemów kodowania, obejmujący klasyfikacje ICD-10 (Międzynarodowa statystyczna klasyfikacja chorób i problemów zdrowotnych), ICD-9 (Międzynarodowa Klasyfikacja Procedur Medycznych), SNOMED (usystematyzowana nomenklatura terminologii w medycynie) i ICF (Międzynarodowa klasyfikacja funkcjonowania niepełnosprawności i zdrowia); rejestr dawców komórek rozrodczych i zarodków; rejestr farmaceutów; rejestr diagnostów laboratoryjnych; lista surowców farmaceutycznych dopuszczonych do obrotu na terytorium RP na podstawie art. 20 ustawy z 6.09.2001 r. - Prawo farmaceutyczne (Dz.U. z 2017 r. poz. 2211 ze zm.); rejestr jednostek współpracujących z systemem Państwowego Ratownictwa Medycznego; ewidencja jednostek systemu Państwowego Ratownictwa Medycznego; ewidencja centrów urazowych, centrów urazowych dla dzieci i jednostek organizacyjnych szpitali wyspecjalizowanych w zakresie udzielania świadczeń zdrowotnych niezbędnych dla ratownictwa medycznego.

${ }^{13} \mathrm{Na}$ niewłaściwe przygotowanie prawne, organizacyjne i techniczne administracji publicznej i podmiotów prowadzących działalność leczniczą do procesu wdrażania poszczególnych elementów systemu informacji w ochronie zdrowia i wynikające z tego 
System informacji w ochronie zdrowia ma być zasilany w sposób rozproszony danymi pochodzącymi z dokumentacji medycznej prowadzonej w postaci elektronicznej przez podmioty wykonujące działalność leczniczą. Referencyjne dane pacjentów będą zatem przechowywane w systemach teleinformatycznych pozostających pod pełną kontrolą tych podmiotów. Zwrócić uwagę należy, że obecnie proces dostosowywania takich systemów do wymagań wymiany danych z SIM ${ }^{14}$, koordynowany przez Ministerstwo Zdrowia i podległe mu jednostki, daje niezadowalające rezultaty, na co wskazują Najwyższa Izba Kontroli w swoich raportach ${ }^{15}$ i wyniki badań ankietowych przeprowadzonych przez Centrum Systemów Informacyjnych Ochrony Zdrowia (CSIOZ) ${ }^{16}$. Godnym rozważenia sposobem rozwiązania tego problemu jest szersze zaangażowanie w te działania medycznych samorządów zawodowych, jak i jednostek samorządu terytorialnego.

Prowadzenie najistotniejszych elementów systemu informacji w ochronie zdrowia, takich jak SIM, platformy P1 i P2 czy rejestry medyczne, pozostaje w gestii ministra właściwego do spraw zdrowia i podległej mu jednostki budżetowej Centrum Systemów Informacyjnych Ochrony Zdrowia. De lege lata przepisy ustawy o systemie informacji w ochronie zdrowia nie przewidują istnienia warstwy regionalnej systemu informacji w ochronie zdrowia, której utrzymywa-

tytułu znaczące opóźnienia w stosunku do pierwotnego harmonogramu przedsięwzięcia zwracała uwagę w swoich dokumentach NIK (Informacja o wynikach kontroli NIK - informatyzacja szpitali, znak sprawy: KZD-4101-05/2012; Informacja o wynikach kontroli NIK - tworzenie i udostępnianie dokumentacji medycznej, znak sprawy: KZD-430-002/2015).

14 Wymagania te zostały określone w rozporządzeniu wydanym na podstawie art. 13a u.s.i.o.z. Na swojej stronie internetowej CSIOZ opublikował ponadto reguły tworzenia elektronicznej dokumentacji medycznej, dokumentację integracyjną P1 w zakresie e-Recepty, a także rekomendacje w zakresie bezpieczeństwa oraz rozwiązań technologicznych stosowanych podczas przetwarzania dokumentacji medycznej w postaci elektronicznej.

15 Informacja o wynikach kontroli NIK - tworzenie i udostępnianie dokumentacji medycznej, znak sprawy: KZD-430-002/2015, s. 33-34.

${ }^{16}$ Badanie stopnia przygotowania podmiotów wykonujących działalność leczniczą do obowiązków wynikających z u.s.i.o.z., https://www.csioz.gov.pl/fileadmin/user_ upload/badanie_ankietowe_2016_5821cc7ea2d3c.pdf (dostęp: 6.01.2018 r.). 
nie stanowiłoby zadanie własne lub zlecone samorządu terytorialnego na poziomie wojewódzkim. Pomimo braku podstawy prawnej dla prowadzenia przez te podmioty tego rodzaju systemów teleinformatycznych rozwiązania takie cały czas powstają. Za przykłady takich przedsięwzięć mogą posłużyć: Podlaski System Informacyjny e-Zdrowie, e-Usługi - e-Organizacja - pakiet rozwiązań informatycznych dla jednostek organizacyjnych województwa kujawsko-pomorskiego obejmujących wdrożenie usług elektronicznych w ochronie zdrowia, Podkarpacki System Informacji Medycznej, Regionalny System Informacji Medycznej Województwa Łódzkiego, Dolnośląskie e-Zdrowie, Małopolski System Informacji Medycznej, e-Zdrowie na Mazowszu, e-Zdrowie w Województwie Świętokrzyskim, Pomorskie e-Zdrowie, Wielkopolskie e-Zdrowie czy Lubuskie e-Zdrowie. Oznacza to, że budowanie takich systemów nie jest odosobnionym przypadkiem w 11 na 16 województw dotychczas podjęto tego rodzaju inicjatywy ${ }^{17}$.

Regionalne platformy przetwarzania danych medycznych powstawały najczęściej jako rezultat projektów współfinansowanych z funduszy strukturalnych UE w ramach instrumentów polityki spójności na lata 2007-2013. W obecnej perspektywie finansowej na lata 2014-2020 takie przedsięwzięcia również są realizowane. Należy zwrócić uwagę, że większość regionalnych systemów informacji medycznej nie oferuje wyłącznie skierowanej do podmiotów wykonujących działalność leczniczą usługi przechowywania elektronicznej dokumentacji medycznej w modelu chmury obliczeniowej (ang. cloud computing), ale stanowi także platformy pośred nie służące do agregacji i zbiorczego przekazywania danych pochodzących z systemów teleinformatycznych takich podmiotów do systemu informacji w ochronie zdrowia. Niewystarczającą zatem podstawą dla takich działań będzie umowa powierzenia przetwarzania zbiorów danych osobowych.

17 Przedstawione zestawienie opracowano na podstawie dokumentu „Analiza Projektów Regionalnych - wyniki II edycji badań”, „Biuletyn Informacyjny CSIOZ” 2014/14-15, https://www.csioz.gov.pl/o-nas/informacja-i-promocja/biuletyn-informacyjny/ (dostęp: 6.11.2018 r.), analizy stron podmiotowych Urzędów Marszałkowskich, a także zebranych samodzielnie przez autora informacji pozyskanych z odpowiedzi na wnioski o udostępnienie informacji publicznej. 
Brak odpowiedniej podstawy prawnej dla prowadzenia systemów teleinformatycznych, przetwarzających przecież wrażliwe dane osobowe dotyczące zdrowia pacjentów, staje się istotnym problemem z punktu widzenia realizacji przewidzianych w art. 9 rozporządzenia UE 2016/679 z 27.04.2016 r. w sprawie ochrony osób fizycznych w związku z przetwarzaniem danych osobowych i w sprawie swobodnego przepływu takich danych oraz uchylenia dyrektywy 95/46/WE18 przesłanek legalizujących tego rodzaju działania. Warto nadmienić, że zgodnie ze stanowiskiem Grupy Roboczej art. 29 „wszelkie dane zawarte w dokumentacji medycznej, w elektronicznej dokumentacji zdrowotnej oraz w systemach EHR należy traktować jako dane osobowe szczególnie chronione"19. Skoro przepis szczególny nie upoważnia samorządu województwa do wykorzystywania takich zasobów $\mathrm{w}$ rozpatrywanych rozwiązaniach informatycznych, to jedyną w praktyce możliwą do zastosowania przesłanką legalizującą takie działania staje się zgoda podmiotu danych. Powinna ona stanowić swobodnie i dobrowolnie podjęte, jak również złożone przed rozpoczęciem procesu przetwarzania danych oświadczenie woli o konkretnej treści, możliwej do jednoznacznej interpretacji, wskazującej w sposób wyraźny na cel wykorzystywania takich zasobów ${ }^{20}$. Biorąc pod uwagę ustawowe obowiązki przekazywania przez podmioty wykonujące działalność leczniczą określonych danych z dokumentacji medycznej pacjenta do systemu informacji w ochronie zdrowia, trudno mówić o dobrowolności zgody tej osoby na przetwarzanie dotyczących jej danych w regionalnym systemie informacji medycznej, który cały ten proces obsługuje $^{21}$. Zachowanie tego aspektu autonomii informacyjnej

18 Dz.Urz. L 119, s. 1. Ten akt prawny jest stosowany od 25.05.2018 r.

19 Dokument roboczy Grupy Roboczej art. 29 w sprawie przetwarzania danych osobowych dotyczących zdrowia w elektronicznej dokumentacji zdrowotnej (EHR), 00323/07/PL WP 131, Bruksela 2007, s. 8.

${ }^{20}$ W sposób szczegółowy przesłanki wyrażenia zgody na przetwarzanie danych osobowych scharakteryzowano w opinii Grupy Roboczej art. 29 nr 15/2011 w sprawie definicji zgody (przyjętej 13.07.2011 r.), 01197/11/PL WP 187 i wytycznych dotyczących zgody na mocy rozporządzenia 2016/679 (przyjętych 28.11.2017 r.).

21 Motyw 43 rozporządzenia UE 2016/679 z 27.04.2016 r. jednoznacznie wskazuje, że jest mało prawdopodobne, by organy publiczne mogły opierać się na zgodzie na przetwarzanie, ponieważ jeżeli administratorem jest taki podmiot, często istnieje wyraźny brak równowagi w stosunkach między administratorem a osobą, której dane dotyczą. 
pacjenta staje się w takim przypadku iluzoryczne. Stosowanie w odniesieniu do takich sytuacji przesłanek dopuszczalności przetwarzania, wyrażonych w art. 9 ust. 2 lit. g-h rozporządzenia UE 2016/679 z 27.04.2016 r. (gdy jest niezbędne ze względów związanych z ważnym interesem publicznym $\mathrm{w}$ dziedzinie zdrowia publicznego lub w związku z zarządzaniem systemami i usługami opieki zdrowotnej) również wydaje się niewystarczające, biorąc pod uwagę treść art. 51 ust. 5 Konstytucji RP i wynikający z tego przepisu obowiązek posiadania odpowiedniej podstawy ustawowej dla gromadzenia danych o osobach fizycznych przez podmioty publiczne ${ }^{22}$. Taka regulacja nie powinna mieć nazbyt ogólnego charakteru, respektując przy tym konieczność zachowania proporcjonalności stosowanych ograniczeń autonomii informacyjnej ${ }^{23}$.

Istotne znaczenie dla omawianego $\mathrm{w}$ tym opracowaniu zagadnienia ma również, wyrażona w art. 71 rozporządzenia UE z 17.12.2013 r. ustanawiającego wspólne przepisy dotyczące Europejskiego Funduszu Rozwoju Regionalnego, Europejskiego Funduszu Społecznego, Funduszu Spójności, Europejskiego Funduszu Rolnego na rzecz Rozwoju Obszarów Wiejskich oraz Europejskiego Funduszu Morskiego i Rybackiego oraz ustanawiającego przepisy ogólne dotyczące Europejskiego Funduszu Rozwoju Regionalnego, Europejskiego Funduszu Społecznego, Funduszu Spójności i Europejskiego Funduszu Morskiego i Rybackiego oraz uchylające rozporządzenie Rady (WE) nr 1083/2006 ${ }^{24}$, zasada trwałości operacji realizowanych w ramach polityki spójności UE i współfinansowanych ze środków funduszy strukturalnych. Trudno oczekiwać należytej realizacji tej zasady w przypadku projektów regionalnych systemów informacji medycznej, których rezultaty nie będą w pełni wykorzystywane ze względu na brak zgody pacjentów na przetwarzanie w tym systemie dotyczących ich danych osobowych.

${ }^{22}$ M. Wild, Ochrona informacji o sobie - art. 51 [w:] Konstytucja RP, red. M. Safjan, L. Bosek, t. 1, Komentarz art. 1-86, Warszawa 2016, s. 1235.

${ }^{23}$ Wyrok TK z 12.12.2005 r., K 32/04, OTK-A 2005/11, poz. 132; wyrok TK z 23.06.2009 r., K 54/07, OTK-A 2009/6, poz. 86.

24 Dz.Urz. L 347, s. 320. 
Decentralizacja systemu informacji w ochronie zdrowia powinna przyczynić się do zwiększenia efektywności i uproszczenia procesów wprowadzania standardów interoperacyjności wymiany zasobów pomiędzy systemami centralnymi, regionalnymi i elektroniczną dokumentacją medyczną prowadzoną przez podmioty wykonujące działalność leczniczą, na co wskazuje przykład Danii ${ }^{25}$. Rozproszenie procesów przetwarzania danych może mieć także pozytywny wpływ na ich bezpieczeństwo, zmniejszając ryzyko utraty dostępności czy poufności takich zasobów informacyjnych w dużej skali na skutek awarii systemów teleinformatycznych lub wystąpienia wyspecjalizowanego, zorientowanego na te rozwiązania ataku cybernetycznego. Należy zwrócić również uwagę, że wyodrębnienie na poziomie wojewódzkim systemów przetwarzania informacji medycznej pozwoli przenieść do nich część funkcjonalności dotychczas realizowanych w rozwiązaniach informatycznych wykorzystywanych w podmiotach wykonujących działalność leczniczą utworzonych przez te jednostki samorządu terytorialnego, co powinno przyczynić się do obniżenia ich obciążeń finansowych związanych $\mathrm{z}$ tym aspektem procesu informatyzacji sektora publicznego.

Biorąc pod uwagę zasadność decentralizacji prowadzenia systemu informacji w ochronie zdrowia de lege ferenda, w przepisach ustawy o systemie informacji w ochronie zdrowia należy uregulować wprost kompetencje samorządu terytorialnego szczebla wojewódzkiego odnoszące się do tworzenia przez te podmioty regionalnych platform informacji medycznej i koordynacji procesów zapewniania interoperacyjności tych rozwiązań z systemami zarządzania elektroniczną dokumentacją medyczną w prowadzonych przez tę jednostkę samorządu terytorialnego podmiotach wykonujących działalność leczniczą. Dla tych regionalnych systemów informacyjnych w ochronie zdrowia powinien zostać dodatkowo uregulowany dopuszczalny zakres przetwarzania danych osobowych pacjentów i cele związane z wykorzystywaniem tych zasobów. Pozwoliłoby niejako usankcjono-

${ }^{25} \mathrm{P}$. Kierkegaard, Interoperability after deployment: persistent challenges and regional strategies in Denmark, „International Journal for Quality in Health Care” 2015/27(2), s. 149-150. 
wać scharakteryzowany wcześniej stan faktyczny związany z istnieniem lub powstawaniem takich rozwiązań informatycznych w większości polskich województw.

Nie można pominąć faktu, że w umowie partnerstwa zawartej między Polską a Komisją Europejską w związku z realizacją polityki spójności na lata 2014-2020 określono cel tematyczny nr 2 „Zwiększenie dostępności, stopnia wykorzystania i jakości technologii informacyjno-komunikacyjnych", obejmujący priorytet odnoszący się do wzmocnienia zastosowań tych technologii dla e-zdrowia. Znajduje on swoje odzwierciedlenie w Regionalnych Programach Operacyjnych polskich województw ${ }^{26}$. Istotne znaczenia ma zatem stworzenie odpowiednich ram prawnych dla takich przedsięwzięć, aby zapewnić należytą trwałość ich rezultatom.

Podsumowując przeprowadzone w tym artykule rozważania, można wskazać, że decentralizacja na szczeblu wojewódzkim obecnie silnie scentralizowanego systemu informacji w ochronie zdrowia powinna pozytywnie wpłynąć na efektywność funkcjonowania tego elementu infrastruktury informacyjnej państwa, a także stan bezpieczeństwa informacyjnego, dzięki rozproszeniu miejsc przechowywania danych osobowych pacjentów.

\section{Bibliografia:}

Kierkegaard P., Interoperability after deployment: persistent challenges and regional strategies in Denmark, „International Journal for Quality in Health Care" 2015/27(2)

Kisielnicki J., Sroka H., Systemy informacyjne biznesu. Informatyka dla zarzqdzania, Warszawa 2005

Oleński J., Infrastruktura informacyjna państwa w globalnej gospodarce, Warszawa 2006

${ }^{26}$ Przykładowo w Regionalnym Programie Operacyjnym Województwa Mazowieckiego na lata 2014-2020 przewidziano oś priorytetową nr 2 „wzrost e-potencjału Mazowsza” obejmującą priorytet inwestycyjny odnoszący się do wzmocnienia zastosowań technologii informacyjno-komunikacyjnych dla e-zdrowia. 
Roos L., Menec V., Currie R., Policy analysis in an information-rich environment, „Social Science \& Medicine” 2004/58

Schmidt-Assmann E., Ogólne prawo administracyjne jako idea porządku. Założenia i zadania tworzenia systemu prawnoadministracyjnego, Warszawa 2011 Szpor G., Informacja w zagospodarowaniu przestrzennym, Katowice 1998

Wąsik D., Ustawa o systemie informacji w ochronie zdrowia. Komentarz, Warszawa 2015

Wild M., Ochrona informacji o sobie - art. 51 [w:] Konstytucja RP, t. 1, Komentarz art. 1-86, red. M. Safjan, L. Bosek, Warszawa 2016 